PIJPSM

45,1

Received 4 June 2021

Revised 10 September 2021 Accepted 22 October 2021

\section{The response of law enforcement agencies and police officers' experiences under the Covid-19 state of alarm in Catalonia, Spain}

\author{
Ana Martínez-Catena and Montse Subirana-Malaret \\ Universitat de Barcelona, Barcelona, Spain, and \\ Falgars Subirana-Malaret \\ Generalitat-Mossos d'Esquadra, Department of Interior, Catalonia, Spain
}

\begin{abstract}
Purpose - Law enforcement agencies and police officers' efforts were crucial to oversee the public health measures and legal regulations introduced during the Covid-19 pandemic. The study had two objectives: to examine the strategies implemented by law enforcement agencies in Catalonia (Spain) to monitor the pandemic and to explore the adverse working conditions of police officers and their personal difficulties during the state of alarm.

Design/methodology/approach - A total of 96 experienced police officers completed a closed-ended, anonymous online survey. In addition, complementary information was collected about the management of law enforcement agencies through open interviews. A descriptive analysis was carried out and the association between variables was explored.

Findings - In general terms, law enforcement agencies managed the uncertainty of the situation, with a focus on official information and communication channels between officers. However, many difficulties were reported by the police officers, such us inconsistency between rules, lack of preventive material or changes in work schedules. Besides, the officers' main concern, beyond the emotional impact suffered during this period, was the possibility of being infected or infecting others.

Practical implications - The congruence between the job requirements and resources, as well as the increase of communication channels during situations of high risk are important variables to assure good job development and personal satisfaction of police officers.

Originality/value - To the knowledge of the authors, at the time of writing this paper, this is the first study in Spain to explore the management of law enforcement agencies and police officers' personal experiences during the Covid-19.
\end{abstract}

Keywords Law enforcement agencies, Police officers, Covid-19, State of alarm, Community police model Paper type Research paper

\section{Introduction}

The outbreak of Covid-19 placed the world in the eye of the storm. The explosion in cases worldwide and the fast spread of the pandemic required extreme international control measures. Undoubtedly, the pandemic constituted an extreme macro-environment with major repercussions and challenges for all organizations (Prouska and Psychogios, 2019). Firstly, during the outbreak and ongoing pandemic, misinformation about Covid-19 and

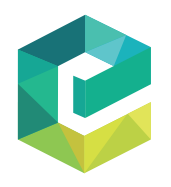

(c) Ana Martínez-Catena, Montse Subirana-Malaret and Falgars Subirana-Malaret. Published by Emerald Publishing Limited. This article is published under the Creative Commons Attribution (CC BY 4.0) licence. Anyone may reproduce, distribute, translate and create derivative works of this article (for both commercial and non-commercial purposes), subject to full attribution to the original publication and authors. The full terms of this licence may be seen at $\mathrm{http}$ ://creativecommons.org/licences/by/4.0/legalcode

The authors wish to thank Mr. Carles Moriscot Capell, Deputy Instructor of the Mossos de Esquadra; Mr. Rafael Ruiz Domínguez, Sergeant of the Local Police; Ms. Montserrat Roig; Ms. Adela Sarabia, and Mr. Josep Montero Guerra, Responsible for SAP-FEPOL services. Thanks to all the participants who supported this study and gave up their time to collaborate. pp. $42-58$

Emerald Publishing Limited

1363-951X

DOI 10.1108/PIJPSM-06-2021-0076
Policing: An International Journa 
conspiracy theories (which generates a state of paranoia in individuals that are searching constantly for dangers in the world and suspecting the worst of every unknown situation or person) were widespread (Friedman, 2021; Kouzy et al., 2020; Mian and Khan, 2020; Stein et al., 2021). To fight against this, the WHO was responsible for reporting on the virus, its evolution and recommended measures at all times. Secondly, at the time of writing this article, the etiological agent remains unclear. Virus mutations have emerged, the effectiveness and slow administration of vaccines is an ongoing issue, we still cannot determine who is most likely to experience the most serious complications of infection (Vieta et al., 2020), and almost every element of Covid-19 is questioned (Durodié, 2020).

Spain was one of the European countries most devastated by the first wave of the Covid-19 outbreak. To fight against the pandemic, the Spanish government decided to adopt immediate control and prevention measures and declared a state of alarm in all Spanish territory from 14 March 2020 by Royal Decree 463/2020. This is the first of three possible types of state of emergency described in the Spanish Constitution, which specifies in which circumstances they can be applied and limits which rights may be suspended. The three states of emergency are: state of alarm, state of exception and state of siege (more information can be found in the regulation Organic Law 4,1981). The state of alarm is the least severe of the three forms but clearly affects the population's rights. The state of alarm can be declared under the following circumstances: (1) natural catastrophes, calamities or public misfortunes, such as earthquakes, floods, urban and forest fires or major accidents; (2) health crises, such as epidemics and serious contamination situations; (3) cessation of essential public services for the community; and (4) situations of shortage of basic needs. The first state of alarm to be declared in Spain since the establishment of democracy was on 4 December 2010 because of air traffic controllers' strikes (Espín, 2018). In this case, the measures only affected air traffic controllers, who were mobilized and considered military personnel. This meant that if they did not go to work in compliance with the orders given to them, they would incur a crime of disobedience of the Military Penal Code. No other state of alarm was declared in Spain until the global outbreak of Covid-19. However, the Covid-19 state of alarm was different as it affected the entire population and led to the application of a wide range of extreme measures to address an unprecedented public health crisis. The measures including limiting people freedom of movement, work conditions or closing roads put at risk the rights of the population. In addition, the supply of food, basic materials and services necessary for public safety had to be maintained. Temporary confiscation was even authorized, if necessary.

To ensure that the extreme measures adopted under the state of alarm were met, a special role was given to law enforcement agencies in Spain, which had to oversee compliance with the measures and regulations, plus monitor them by legal order from the 15th March, Order INT/226 (2020). To do so, they were authorized to carry out the necessary checks on people, goods, vehicles, establishments etc. and to prevent and suspend the activities or services that should not be occurring.

\section{Catalan law enforcement institutions: model of work and competences}

After Franco's dictatorship and on the path to a democratic political system, police or law enforcement institutions in Spain were given a new division and structure described in the Spanish Constitution of 1978. This new structure distinguished three levels: police of the central state administration, police of autonomous communities and local police who are dependent on municipal power.

The Mossos d'Esquadra is the Catalan autonomous community police force. Once democracy had been established in Spain, the Catalan Government introduced a new police force by means of Law 19/1983, of 14 July, of the Parliament of Catalonia. The aim was to create a professional, well-trained force, in line with an advanced, democratic society. The Mossos d'Esquadra police force was set up along with the Policia Local (local police, 
PIJPSM

45,1 municipal police or city guard), who are distributed in different municipalities of the Catalan territory and jointly responsible for police work.

Unlike other organizations, law enforcement agencies are regulated by government institutions and legal regulations. The police organization has to take ownership and responsibility for the framework regulations, which provide for political actions. Currently, the framework, political actions and competences of public security forces in Catalonia are regulated by Law 4/2003, of 7 April, on the Organization of the Public Security System of Catalonia.

The legal framework assures that the police task is focused on guaranteeing the exercise of rights and freedoms of the individual and public safety (Law 10/1994, of 11 July). Police competences can be divided into areas of action: citizen security, administrative police, judicial police, intervention in the resolution of private conflicts, cooperation and collaboration with local entities, and traffic police (Organic Law 6, 1997). The Policia Local only act within their municipality and its competences are: security in public places, regulation of the transit of vehicles and people on urban roads, civil protection and the administrative field. The scope of action for the Mossos d'Esquadra extends throughout all the territory of Catalonia and it is a comprehensive police force. Therefore, it includes public safety, public order, administrative police, and the control of Catalan roads, emergencies and civil protection, and the most serious crimes including organized crime and terrorism. Both law enforcement agencies are ruled by the principles of complementarity, coordination, collaboration, cooperation and mutual assistance. In parallel, the Mossos d'Esquadra must coordinate and collaborate with the rest of the state law enforcement agencies.

Regardless of the area of action, the competences of police agencies are related with the legal framework, which is based on the foundation of proximity. Proximity policing, also known as community policing or community-oriented policing (COP), is a model that defines the culture of modern and new police force organizations. It determines the framework and performance of its workers. In turn, COP guides the organizational culture, strategy and work methodology. Its purpose is to involve the police in problems that directly affect the quality of life in communities, districts or neighborhoods (Jarillo, 2020).

Notable among the operational strategies are planned patrolling and the proactive (as opposed to reactive) system; problem solving; a decentralized, value-based structure; and results evaluation. The officers have to gain community trust and collaboration as coresponsible agents in security matters. To achieve this, officers are trained to develop problem-solving and relational skills, including efficient communication and emotional intelligence, mediation techniques and negotiation in conflict resolution (Jarillo, 2020).

More than ever, evolving needs and the complex socio-economic reality require a proximity police model that guarantees the provision of the police service. This is one reason why recent international research about the role of the police force under Covid-19 has highlighted the need for a model focused on humanitarian help (Alcadipani et al., 2020a, b). In this sense, a survey about the general opinion of 5.918 citizens on the job of the Law enforcement agencies was developed by the Catalonia Home Office in 2017. In this survey the Mossos d'Esquadra were valued with 7.8 points in a range of $0-10$ (10 being an opinion of excellent development), and the Policia Local with 7.3 points (Catalonia Home Office, 2018). During or after the pandemic no formal surveys have assessed the opinion of the public, however many grateful letters of the citizens were received by the law enforcement agencies and published on social networks. Furthermore, the social movement of clapping every night during the confinement to encourage and be grateful to the health professionals was also extended to the police officers.

\section{Impact of the pandemic on frontline workers or street bureaucrats}

During the state of alarm, several circumstances due to the precautionary measures, recommendations and management of the pandemic affected the lives of workers, particularly those known as street-level bureaucrats (SLBs): health professionals, social 
workers and state security forces (Lipsky, 1980). SLBs provide essential services and fight on the front lines. Under Covid-19, SLBs interacted daily with complex situations in which the law, citizens' personal needs and public health requirements sometimes clashed. This situation forced SLBs to make new or different decisions in their jobs every day.

The interaction and emotional engagement of SLBs and police officers with citizens, along with work environments with a high workload, unpredictability and ambiguity, may lead to symptoms of distress (Braquehais et al., 2020; Riedy et al., 2021; Tummers et al., 2015); PTSD, anxiety, insomnia and/or depression (Navin et al., 2020; Pappa et al., 2020; Wagner et al., 2019); alienation, depersonalization, emotional exhaustion, surface acting, burnout (Adams and Mastracci, 2020), decoupling and coping practices (Johnson and Vaughn, 2016; Knight, 2017); or even increased risk of suicide mortality (Baumert et al., 2014).

In particular, Stogner et al. (2020) hypothesized that some of the consequences that Covid-19 could have on police officers are stress, mental health issues and resilience. For these authors, one of the closest analogies to the climate produced by Covid-19 in law enforcement agencies is the spread of HIV in the 1980s, when officers described a pervasive fear of the virus. Limited knowledge about sickness transmission caused stress and dissuaded officers from assisting injured citizens, a situation that could be very similar to the circumstances produced by Covid-19 during the first months of the pandemic. According to these hypotheses, Frenkel et al. (2021) analyzed a broad sample of police officers from European countries and concluded that the risk of infection with Covid-19 and deficient communication were the main stressors.

Other published studies have paid more attention to policing measures and to the demand changes and adaptation of the organization to the pandemic. Overall, the conclusions emphasized the use of mixed strategies to get over the pandemic, for example: increasing communication and information within the organization, increasing online work, diminishing traffic controls and other similar activities and suspending training activities, among other impacts (Luong et al., 2020; Maskály et al., 2021).

The first weeks after the declaration of the state of alarm were some of the worst moments throughout the pandemic in Spain for several reasons: the high number of active cases and human deaths, the lack of protection resources for the population, the overcrowded and underresourced hospitals among others, besides the unexpected escalation of the situation. The nature of the context required a fast adaptation of police officers' duties and the affectation of the citizen rights was the biggest one enforced in the recent history of the country. Although it is clear that the pandemic has had an effect on law enforcement agencies and officers' experiences, to the best of this author's knowledge, no research has been undertaken in Spain yet.

For these reasons, this study intends to examine the following objectives: first, to analyze in detail the adverse working conditions experienced by police officers along with the personal and emotional impact of the pandemic during the first declaration of the state of alarm in Spain from 14 March to 21 June 2020. Second, to describe how law enforcement organizations interacted with the state of alarm, the mechanisms used and the changes implemented to overcome the situation and how this shaped police officers' experiences.

\section{Method}

Participants

This study is composed of an advisory committee and the survey participants sample. The advisory committee was comprised of 6 members $(60 \%$ men, $40 \%$ women; aged between 40 and 55 years old). The inclusion criteria to be part of this advisory committee were to be a member of any law enforcement agencies with a minimum of ten years' experience and to have a degree level studies or specialized training regarding the law enforcement job. 
PIJPSM

45,1

46

As for the survey sample, initially 190 police officers from the various law enforcement services in Catalonia started the online, closed-ended anonymous survey. The only inclusion criteria consisted of being part of the law enforcement services in Catalonia. However, despite many police officers started the survey only 96 completed the whole questionnaire.

For this reason, the final sample was composed of 96 police agents: 20 women $(20.8 \%)$ and 76 men $(79.2 \%)$. Their mean age was 46 years old $(\mathrm{SD}=6.8$; $\min .22$; max. 63$)$. The police officers who participated in this study are from the various law enforcement services in Catalonia: 79 (82.3\%) officers from the Mossos d'Esquadra, 17 (17.7\%) officers from the local police (including the Guàrdia Urbana de Barcelona).

The following Table 1 shows some of the sample's family characteristics that were considered relevant to an analysis of the state of alarm because of their capacity to increase police officers' stress.

\section{Instruments}

The online survey was developed collaboratively between the research team and the advisory committee. The survey guaranteed anonymity and confidentiality to participants.

The survey consisted of 23 closed-ended questions (someones containing several items) divided into four sections:

(1) Sociodemographic and professional career variables were explored through 19 open and closed-ended items.

(2) Exceptional experiences during their job performance and for how long those experiences lasted, included 19 items assessed in the range 0 "not suffered" to 9 "suffered until week 9 of the state of alarm" (as the questionnaire was only available online during for the first 9 weeks, which was the duration of the first state of alarm). Questions were divided into five categories of interest: the organization's lack of resources and deficient management of the organization, including items about institutional difficulties in monitoring the pandemic. The health concerns category included three items related to fear of infection. The impact on work conditions were four items on situations that affected the work experience and the last category, personal consequences derived from the state of alarm, included five items on other changes that officers reported as personal difficulties experienced during this period.

\begin{tabular}{lcc}
\hline Variables & $N$ & $(\%)$ \\
\hline Couple relationship & & \\
No & 17 & $(17.7)$ \\
Yes, without living together & 13 & $(13.5)$ \\
Yes, living together & 66 & $(68.8)$ \\
Children in their care & & \\
No & 12 & $(12.5)$ \\
One child & 19 & $(19.8)$ \\
Two children & 50 & $(52.1)$ \\
Three or more children & 15 & \\
Cohabitation unit during the state of alarm & & $(6.3)$ \\
Alone & 6 & $(9.4)$ \\
Couple (without children) & 9 & $(65.6)$ \\
Couple and children & 63 & $(11.5)$ \\
With children (no couple) & 11 & $(5.2)$ \\
Family of origin (parents, grandparents, etc.) & 5 & $(2.1)$ \\
Others & 2 &
\end{tabular}

Table 1.

Description of the sample's family characteristics

\section{Others}


(3) Emotional distress and symptomatology. Emotional distress was assessed through two items on the emotional impact that officers had experienced in the past and during Covid-19. These items asked them to think about situations that could have produced them negative emotions or symptomatology (even if they did not require psychological support or sick leave) and including situations in which their lives were in danger. These items were assessed on a range from 0 "no situations", 1 "between 1 and 5 situations", 2 "between 6 and 10 situations" and 3 "more than 11 situations of emotional impact". This scale was suggested by the advisory committee. Additionally, one item directly asked about feelings of emotional stress (on a Likert scale ranging from 0 "emotion not felt" to 3 "felt frequently/daily"). Symptoms related to stress were also assessed through 11 items on a Likert scale ranging from 0 "not suffered" to 3 "suffered frequently/daily").

(4) Healthcare habits implemented previously (12 items) and during the state of alarm (12 items) were assessed through yes/no questions.

Due to length limitations, in this paper we focus on sections 1,2 and 3 of the questionnaire.

\section{Procedure}

Considering the inside management of law enforcement agencies is unknown to the general population in Spain an advisory committee of police officers was created. These members volunteered to a general request done by the researchers in their professional social network. The advisory committee had to participate in several open interviews regarding the second objective of this study (the results of the interviews are exclusively described in the subheading "Catalan law enforcement institutions: model of work and competences"). Due to confinement, all collaborators were interviewed through a minimum of three videocalls with a duration of one and a half hours each one.

This advisory committee also supported the researchers in the development of the webbased questionnaire, reviewing the terminology related to their police organizations, assuring we included all relevant items and correct answer scales. Some adjustments were made to the questionnaire according to their professional suggestions.

The final web-based survey questionnaire was posted online using Qualtrics software. An email/WhatsApp invitation was sent to many of the potential participants with the help of a member of the advisory committee. The email/WhatsApp title explained the aims of the study and guaranteed anonymity and confidentiality to participants. Participants were prompted to forward the questionnaire to other colleagues, and it was distributed using the snowball technique. The survey remained open from 24 April to 21 June of 2020. The research was carried out entirely during the first declaration of state of alarm that as mentioned before represents the moment in which the pandemic was out of control, and it required the quickest adaptation of police officers' duties.

The collected data were analyzed with SPSS statistics software, mainly using descriptive analysis. From an exploratory perspective, the relationships between variables were analyzed using the Pearson and Spearman correlations, the $Z$ test for proportions, the chi square test and ANOVA comparisons of means. Only the most relevant significant results are included here.

\section{Results}

Personal characteristics and professional experience of a sample of police officers

Police officers had a mean of 18.8 years $(\mathrm{SD}=7.5$; Min. $=1 / \mathrm{Max} .=36)$ of professional experience as officers and a mean of 13.0 years $(\mathrm{SD}=7.2$; Min. $=0 / \mathrm{Max} .=30)$ of experience in their current job area. 
PIJPSM

45,1

Details about the police officers' jobs, specifically their rank in the agency and the kind of tasks they carry out are shown in Table 2. Most of the sample had the rank of police officer/ patrol officer $(67.7 \%)$, traffic control (14.6\%), citizen security (37.5\%), judicial police $(18.8 \%)$ and public order police $(7.3 \%)$.

Regarding their previous professional experience, before the state of alarm for Covid-19, the $68.8 \%$ of sample had participated in other special devices to deal with an exceptional situation in which the lives of many people were endangered. In particular, the operations were activated by biological/contagion risk (3.1\% officers), ETA terrorism (Spanish terrorism) $(16.7 \%)$, Islamic terrorism $(53.1 \%)$, social turbulence for political reasons $(32.3 \%)$, natural disasters $(36.5 \%)$ and others (3.1\%). On average, police officers had participated in 2.1 of the previously described operations $(\mathrm{SD}=1$, Min. $=1 / \mathrm{Max} .=4)$.

Table 3 describes police officers' job situation during the state of alarm for Covid-19. A total of $61.5 \%$ of the police officers were working in the frontline (direct contact with citizens).

Organizational adaptation to pandemic requirements: emphasizing communication

According to the interviews developed to the advisory committee, the communication between government, police organization and workers is crucial. The two most frequently used

\begin{tabular}{lrr}
\hline Variables & $N$ & $(\%)$ \\
\hline Police officers' ranks & & \\
Police officer/patrol officer & 65 & $(67.7)$ \\
Corporal & 16 & $(16.7)$ \\
Sergeant & 4 & $(4.2)$ \\
Sub-inspector & 3 & $(3.1)$ \\
Inspector & 2 & $(2.1)$ \\
Superintendent & 1 & $(1.0)$ \\
Others & 5 & $(5.2)$ \\
Area of work & & \\
Traffic control & 14 & $(14.6)$ \\
Citizen security & 36 & $(37.5)$ \\
Judicial police & 18 & $(18.8)$ \\
Forensics & 2 & $(2.1)$ \\
Evidence technician & 2 & $(2.1)$ \\
Central command room & 1 & $(1.0)$ \\
Public order police & 7 & $(7.3)$ \\
Specialized groups & 1 & $(1.0)$ \\
Training & 3 & $(3.1)$ \\
Intelligence & 2 & $(1.1)$ \\
Others & 10 & \\
\end{tabular}

Table 2.

Description of the sample's job placement

\section{Table 3.}

Working situation of police officers during the state of alarm for Covid-19

\begin{tabular}{lcc}
\hline Working situation & $N$ & $(\%)$ \\
\hline Working in the frontline (direct contact with citizens) & 59 & $(61.5)$ \\
Working but not in the front line (offices, training, etc.) & 18 & $(18.8)$ \\
Locked down with online work & 6 & $(6.3)$ \\
Locked down without online work & 3 & $(3.1)$ \\
Infected and sick with Covid-19 & 5 & $(5.2)$ \\
On sick leave due to a common illness & 4 & $(4.2)$ \\
Temporary change of job to other tasks & 1 & $(1.0)$
\end{tabular}


information channels in the Mossos d'Esquadra are the daily briefings and the corporate intranet. Daily briefings are held by all units at the beginning of the shift to update the incoming service and report any relevant events that took place in previous shifts. The corporate intranet contains all the information needed to carry out the daily work (documentation, rules and laws, etc.) and to train workers, and the main press clippings or links of interest to departments and communication networks that may be of use to police work.

However, as will be described below, the emerging pandemic of Covid-19 led to an increase in communications and operational work changes. A total of seven informational/operational publications were made during the first break. A part from the abovementioned daily briefings and corporate intranet, new communication systems were open between police officers and the organization, and a constant reminder of the support services available to them.

This started with an informative communication at the end of January 2020 that was published on the corporate intranet, essentially for prevention purposes. It contained information about symptoms, forms of transmission, prevention measures and guidelines on what to do when dealing with a suspected case of the new virus.

In the first fortnight of March, when the state of alarm was declared, the Secretary General of the Interior's instruction was published on the corporate intranet. This described the organizational measures to take to enable care, operations and protection of the rights and property of the population and to ensure the security and health of police agents and all the professional groups under its direction. Since then, several other documents were published: (1) an internal communication of the chief commissioner with specific instructions to comply with the aforementioned instruction; (2) ORIS, an operational plan to coordinate a group of order within PROCICAT (the action plan for civil protection), which was updated as the measures were modified by the main government; (3) the resolution of the general director of police on 12 March, modifying the distribution of the working day, and an internal communication to staff on the mobilization of all services, with schedule changes becoming effective on $14 \mathrm{March}$; (4) internal communications to police officers and all workers to receive operational instructions on the state of alarm and information on how to proceed as the state of alarm was prolonged and the measures were modified weekly, and (5) the police headquarters' action plan for SARS-Cov-2, where all the information was collected.

A specific contact and support e-mail box were also created so that all staff could express their doubts. These doubts were used to create a specific frequently asked questions (FAQs) section on the intranet, which was modified and extended periodically.

Information sheets and infographics on prevention and protection measures created by the Sub-Directorate General of Occupational Health and Risk Prevention were published by the operational bodies of the Department of the Interior.

Psychological recommendations were published to deal with the health crisis and an email contact box was established in case psychological support was needed.

Finally, non-official networks were established between close groups of workers through instant messaging networks, such as WhatsApp, as police officers needed to discuss doubts with their closest commander and share personal or emotional needs with colleagues.

\section{Adverse work conditions and police officers' experiences during the Covid-19 state of alarm}

Most of the police officers in the sample experienced several adverse conditions during this period, as shown in Table 4. Workers reported that these difficulties were still unresolved eight weeks after the declaration of the state of alarm. The main difficulties were the lack of PCR testing at work (95.8\% officers), the risk of being infected (94.8\%), infecting someone in the unit of cohabitation (94.8\%), infecting a citizen during work (90.6\%), and the incongruence between rules, material and resources provided by the agency $(89.6 \%)$.

The analysis of these variables showed many significant correlations between all the difficulties. This analysis is shown in Appendix, Spearman correlations between the main 


\section{PIJPSM} 45,1

50
Difficulties identified

$N$

$(\%)$

Institution lack of resources

Lack of PCR testing at work

Lack of self-protection measures and material to prevent infection

Lack of specialized psychological support

Lack of enough crew/human resources

Deficient management by the organization

Incongruence between rules, material and resources provided by the agency

Lack of clear orders for incident management

Unclear information about sanitary measures in the police station

Lack of planning, strategies or action protocols

Lack of coordination with other security institutions

Health concerns

Being infected him/herself

Infecting someone in the unit of cohabitation

Infecting a citizen during work

Impact on work conditions

Working with colleagues who do not respect sanitary or work rules

Lack of personal resources to face the situation

Changes in work schedules

Being unable to give clear orders to my team

Personal consequences derived from the state of alarm

Prohibition of doing sport outside

Difficulties in the work-life balance $\quad 72$

Impossibility of isolating myself

Having to reveal a previous pathology

difficulties experienced by officers. Expected relationships were found. For instance, the lack of preventive material and PCR tests seemed to be correlated strongly with health concerns; the lack of personal resources to face the situation correlated with unclear information about public health measures in the police station and the lack of specialized psychological support, etc. Interestingly, the difficulties in achieving a work-life balance were more strongly correlated with a lack of planning, strategies or action protocols and a lack of clear orders for incident management than with work schedule changes.

\section{Exploration of the emotional distress experienced by officers during COVID-19's state} of alarm

As for emotional exposure, only $12.5 \%$ of the sample reported that they had never suffered an emotionally shocking situation during their professional experience. However, as shown in Table 5 , most of the participants had suffered between 1 and 5 emotionally shocking

Table 5.

Comparison of emotionally shocking situations experienced before and during Covid-19 state of alarm

Frequency Before Covid-19 state of alarm
$N(\%)$

$12(12.5)$

$57(59.4)$

$21(21.9)$

$6(6.2)$
During Covid-19 state of alarm $N(\%)$

$34(35.4)$

$48(50.0)$

$6(6.3)$

$4(4.2)$ 
situations in the past (59.4\% officers). Unexpectedly, during the Covid-19 state of alarm, the percentage of police officers who did not suffer any emotionally shocking situations increased to $35.4 \%$, but the percentage of participants who reported between 1 and 5 situations was the highest (50\%). The $Z$ test for proportions did not show any differences between emotional impact situations experienced before and during the state of alarm. However, police officers who participated in previous special devices like terrorism alarms or social turbulences (described before in the subheading Personal characteristics and professional experience of a sample) showed significantly higher proportions of emotional impact $(64.9 \%$ of police officers) than those who did not participate $(22.9 \%)$. In addition, chi square analysis showed a significant association between emotional impact before Covid-19 and participation in previous special operations $\left[\chi^{2}(2, n=96)=8.008 ; p=0.018\right]$. On the contrary, participation in previous special operations was not associated with the proportions of emotional impact during the Covid-19 state of alarm.

The possible association between emotional impact during the state of alarm and the previously described variables was analyzed in greater depth. Only one significant association was found between emotional impact during state of alarm and gender $\left[\chi^{2}(2\right.$, $n=92)=8,541, p=0.014]$. A total of $90 \%$ of women indicated that they experienced situations of high emotional impact. In men, the percentage was lower (55.5\%). Interestingly, this gender association was not found with emotional impact before Covid-19, suggesting maybe the experience lived during COVID-19 was different for men and woman. Further analysis is required to explore this association. No associations were found with other sociodemographic variables (like age, having a partner or having children).

Officers had a low score for stress-related symptoms, with a mean of $7(\mathrm{SD}=4.326)$ in a range between 0 and 44 points. In addition, they reported a low average of 1 point $(\mathrm{SD}=0.842)$ for feelings of stress, in a range of $0-3$. No significant differences in the emotion of stress were found by gender.

However, as expected, the ANOVA analysis indicated that individuals who stated they had experienced more situations of greater emotional impact during Covid-19 expressed significantly higher levels of stress symptoms $[F(2,91)=5.038, p<0.001]$ and feelings $[F(2$, 91) $=6.606, p=0.002]$.

Most workers $(70.8 \%)$ reported they did not know of the existence of a psychological support service during the state of alarm, and a few others knew of the existence of a psychological support service, but not well enough.

\section{The sample's perceptions of organization and their own efficacy to face this period}

When the sample was asked about their opinions on organizational efficacy and the management of the situation, considering the resources and information that their organization normally has, $62.5 \%$ of the workers believed that the institution had not been effective enough. However, the police organization did not obtained the worst rating compared to other institutions associated with managing the state of the alarm. Table 6 shows opinions of the performance of various institutions on a range from 0 to 10 points ( 0 is very bad performance and 10 is perfect or almost perfect performance). Their police

\begin{tabular}{lcrr}
\hline Institutions & Mean & (SD) \\
\hline Own police agency & 6.27 & 2.473 & \\
Autonomous government & 4.76 & 2.612 Workers' opinion of the \\
City/town government & 5.90 & 3.221 & performance of \\
Spanish government & 3.95 & 2.066 & institutions \\
& & &
\end{tabular}

\section{Response of law enforcement agencies}

51 
PIJPSM

45,1

organization received a mean of 6.3 points $(\mathrm{SD}=2.47)$, which was the second highest rated, after the city/town council $(M=8.00, \mathrm{SD}=3.90)$ (Table 6$)$.

In contrast, most of the survey participants $(86.5 \%)$ reported they felt satisfied with their personal abilities to face the situation and the $69.8 \%$ of police officers felt satisfied with their job performance during this period, for different reasons. Most of the workers gave reasons related with the feeling of being useful for society and for the fight against the virus (38.6\%). This made them feel fulfilled personally and professionally. In addition, other police workers stated that they were satisfied because they were accomplishing their job despite difficulties and a lack of resources $(29.8 \%)$ and they perceived that they were contributing to strict reinforcement and compliance with the rules, even among themselves $(17.5 \%)$. Finally, some police officers reported satisfaction from supporting the work of other colleagues $(5.3 \%)$ and others enjoyed the personal challenge of overcoming work conditions and the social situation $(8.8 \%)$.

Associations between feeling satisfied with their job and the previous variables were also explored. The only significant association that was found was with the variable impossibility of quarantining alone $\left[\chi^{2}(1, n=96)=6.001, p=0.014\right]$. More police officers felt satisfied when they had the opportunity to isolate themselves $(85.3 \%)$ than when this was not possible $(61.3 \%)$.

\section{Discussion}

This paper explores the impact of the Covid-19 state of alarm in Spain on the management of law enforcement organizations, their workers' experiences and response. The results showed several adversities at work and personal difficulties that officers faced during the state of alarm. The main difficulty reported by officers was the lack of material resources to prevent infection (PCR test, availability of masks, gloves, etc.). This was a serious situation that could have affected how they did their job. However, it must be remembered that some preventive materials were completely unavailable in Spain (and in other European countries) for workers and the general population. Only when the country started to acquire these materials could law enforcement institutions provide some for their workers.

Other shortfalls that were pointed out were related to the management of the organization, in terms of incongruence between rules, a lack of clear orders, unclear information about public health measures, etc. The lack of information was highlighted in other studies as an important source of stress for officers during the pandemic (Frenkel et al., 2021). However, in this case, increasing all sorts of information may have made the workers confused.

As has been largely documented in this paper, law enforcement organizations and their action plans are regulated according to the legal framework on which they rely. This means that clear, learned protocols, regulations and laws tend to be stable and unmodifiable. For these reasons, we suggest that it may be necessary to lose the association between strict bureaucratic control and the response to changing environments for street-level decisionmaking by workers. As Johnson and Vaughn (2016) explained, for those on the frontline it could be beneficial to overcome extreme situations like those created by the Covid-19 pandemic. In parallel, it would have been useful to accompany the new protocols with a process of training and support to completely ensure understanding and alignment of the changes.

In line with previous studies, the overwhelming majority of police officers were worried about the possibility of infection during their work in interactions with citizen. This concern seems logical if we consider the complete lack of preventive measures experienced by the officers over a long period of time. The correlation analysis indicated that all difficulties experienced by the officers were correlated. This suggests that many difficulties could interact and multiply the stress on police officers. 
A total of $60.5 \%$ of the police officers reported that they had been exposed to situations of strong emotional distress during the state of alarm. However, the number of stressful situations experienced by police officers prior to Covid-19 seemed to be higher (87.5\%). This may be related to one limitation of this paper: the fact that a comparison was made between long professional careers (most of around 10 years) and the few weeks or months of work during the state of alarm. However, the impact was still relevant, considering the personal emotional baggage of the workers.

Perhaps what is more important in this area is the experience of officers in previous exceptional operations, rather than the overall time dedicated to duty. The probabilities of encountering emotionally shocking situations could be greater under these special circumstances, such us terrorist alarms. In addition, it should be considered that previous experiences in special operations will have contributed to gaining a certain level of habituation and neutralization of emotional impact. In accordance with these results, the officers who experienced more emotional situations reported significantly higher levels of symptoms and feeling of stress.

In terms of gender differences, more situations of emotional impact were perceived and reported in women than men. The specialized literature indicates that female officers usually suffer higher levels of anxiety (Stogner et al., 2020). However, no significant differences were found in this aspect. These results suggest that women report they have experienced situations that they consider as emotionally impacting but do not seem to increase their anxiety or stress levels. Perhaps, more analysis would be interesting to explore the relationship between the situations lived and the anxiety levels, as well as the coping mechanisms women used to reduce the impact of the situations lived.

Finally, $69.8 \%$ of the police officers felt satisfied with the way they carried out their job during this period and $86.5 \%$ felt satisfied with their personal abilities. Interestingly, the possibility of isolating was a variable associated with officers' satisfaction with their job. Possibly, when officers could isolate themselves during the state of alarm and not worry about infecting family members, their job performance was better. This possibility was available to only a few police officers. In contrast, health professionals were offered special residences or hotel rooms by the government and other organizations to facilitate their job, access to hospitals and isolation.

\section{Conclusions and limitations}

This is the first study in Spain about the experiences of law enforcement agencies and police during the Covid-19 first state of alarm. Also, we believe this study provides information about the functioning of the law enforcement agencies from Spain in extreme situations that to the knowledge of this authors has never been published.

As a general conclusion, the results of this study reveal that it was feasible for workers to adapt to adverse working conditions due to Covid-19 and adaptation was more successful than expected. Police officers coped with the situation without experiencing higher levels of emotional distress or anxiety. However, the main difficulties were originated by the lack of resources and protection material during the pandemic. Organizational difficulties were essentially due to external reasons rather than the structure or management of the organization. For the future, one of the main lessons taken from this experience is the necessity of congruence between the job requirements and the availability of resources to help police officers to accomplish their duties with personal security. A second important conclusion is that increasing communications either through formal or informal channels between the agency and the police officers can be highly useful to the management of high-risk situations in the future. As long as the organization assures they are fully understood by officers.

However, there are some limitations. Firstly, the final sample was small, even though the questionnaire was open to every police officer in Catalonia, this population is very reluctant to 
PIJPSM

45,1

\section{4}

participate in research that involves revealing personal and work information, despite the confidentiality of the data. In addition, the officers had a heavy workload during the study period, which perhaps did not help to reach a wider sample.

A second limitation of this study is the lack of data obtained through validated questionnaires about stress, depression or other mental health variables. However, in addition to the referred reluctance of the sample in front of validated instruments, it has to be noticed that very few short and validated instruments are available in Spanish or Catalan (main language of Catalonia law enforcement organizations). All in all, the advisory committee recommended to obtain the information about stress, depression or other mental health variables through the $a d$ hoc questionnaire already described rather than specialized questionnaires in order to achieve a bigger sample in this study. Regardless, in the study presented here a lot of information was obtained during a critical period on a very underresearched population. This is a starting point for further and promising collaborations that could be carried out in the future with the collaboration of the law enforcement organizations, especially to identify best practices that can improve the management of high risk situations and the performance and personal experiences of police officers.

\section{References}

Adams, I.T. and Mastracci, S.H. (2020), "Contrasting emotional labor and burnout in civilian and sworn law enforcement personnel”, Policing, Vol. 43 No. 2, pp. 314-329, doi: 10.1108/PIJPSM-062019-0094.

Alcadipani, R., Cabral, S., Fernandes, A. and Lotta, G. (2020a), "Street-level bureaucrats under COVID-19: police officers' responses in constrained settings", Administrative Theory and Praxis, Vol. 2 No. 3, pp. 394-403, doi: 10.1080/10841806.2020.1771906.

Alcadipani, R., Cabral, S., Fernandes, A. and Lotta, G. (2020b), "Administrative theory and praxis street-level bureaucrats under COVID-19: police officers' responses in constrained settings", Administrative Theory and Praxis, Vol. 42 No. 3, pp. 394-403, doi: 10.1080/10841806.2020. 1771906.

Baumert, J., Schneider, B., Lukaschek, K., Emeny, R.T., Meisinger, C., Erazo, N., Dragano, N. and Ladwig, K.H. (2014), "Adverse conditions at the workplace are associated with increased suicide risk", Journal of Psychiatric Research, Vol. 57 No. 1, pp. 90-95, doi: 10.1016/j.jpsychires.2014. 06.007 .

Braquehais, M.D., Vargas-Cáceres, S., Gómez-Durán, E., Nieva, G., Valero, S., Casas, M. and Bruguera, E. (2020), "The impact of the COVID-19 pandemic on the mental health of healthcare professionals", QJM: An International Journal of Medicine, Vol. 113 No. 9, pp. 613-617, doi: 10. 1093/qjmed/hcaa207.

Catalonia Home Office (2018), Enquesta de seguretat pública de Catalunya, edició 2017. [Survey of public security of Catalonia, edition 2017], Generalitat de Catalunya, Barcelona.

Durodié, B. (2020), "Handling uncertainty and ambiguity in the COVID-19 pandemic", Psychological Trauma: Theory, Research, Practice, and Policy, Vol. 12 No. S1, pp. S61-S62, doi: 10.1037/ tra0000713.

Espín, L. (2018), "Estado de alarma en el sistema constitucional español: espacio aéreo”, Revista Acta Judicial, Vol. 2 No. 2, pp. 115-131, available at: https://etradosdejusticia.es/revistaactajudicial/ index.php/raj/article/view/16.

Frenkel, M.O., Giessing, L., Egger-Lampl, S., Hutter, V., Oudejans, R.R.D., Kleygrewe, L., Jaspaert, E. and Plessner, H. (2021), "The impact of the COVID-19 pandemic on European police officers: stress, demands, and coping resources”, Journal of Criminal Justice, Vol. 72 No. 101756, pp. 1-14, doi: 10.1016/j.jcrimjus.2020.101756.

Friedman, R.A. (2021), "Why humans are vulnerable to conspiracy theories", Psychiatric Services, Vol. 72 No. 1, pp. 3-4, doi: 10.1176/APPI.PS.202000348. 
Jarillo, F.J. (2020), Policia de proximitat. Dins l'organització de la policia local de Blanes, Ajuntament de Blanes, Blanes.

Johnson, A.D. and Vaughn, M.S. (2016), "Decoupling and police organizational structure", Administrative Theory and Praxis, Vol. 38 No. 3, pp. 157-167, doi: 10.1080/10841806.2016.1173942.

Knight, G.M. (2017), "The impact of loose coupling on police effectiveness", Australian and New Zealand Journal of Criminology, Vol. 50 No. 2, pp. 269-281, doi: 10.1177/0004865815620704.

Kouzy, R., Abi Jaoude, J., Kraitem, A., El Alam, M.B., Karam, B., Adib, E., Zarka, J., Traboulsi, C., Akl, E. and Baddour, K. (2020), "Coronavirus goes viral: quantifying the COVID-19 misinformation epidemic on twitter", Cureus, Vol. 12 No. 3, doi: 10.7759/cureus.7255.

Law 10/1994, Ley 10/1994, de 11 de julio, de la Policía de la Generalidad-«Mossos d'Esquadra». Comunidad Autónoma de Cataluña". «DOGC» núm. 1923, de 20 de junio de 1994, available at: https://www.boe.es/buscar/pdf/1994/BOE-A-1994-18777-consolidado.pdf.

Law 19/1983, "Ley 19/1983, de 14 de julio, por la que se crea la Policía Autonómica de la Generalidad de Cataluña.Comunidad Autónoma de Cataluña”. «DOGC» núm. 347, de 22 de julio de 1983, available at: https://www.boe.es/buscar/pdf/1983/DOGC-f-1983-90046-consolidado.pdf.

Law 4/2003, "Ley 4/2003, de 7 de abril, de Ordenación del Sistema de Seguridad Pública de Cataluña.Comunidad Autónoma de Cataluña”. «DOGC» núm. 3865, de 15 de abril de 2003, available at: https://www.boe.es/buscar/pdf/2003/BOE-A-2003-9620-consolidado.pdfç.

Lipsky, M. (1980), Street-Level Bureaucracy: Dilemmas of the Individual in Public Services, Russell Sage Foundation, New York, doi: 10.1177/003232928001000113.

Luong, H.T., Jardine, M. and Thomson, N. (2020), "Mobilizing the police from the top down as public health partners in combatting COVID-19: a perspective from Vietnam", Journal of Community Safety and Well-Being, Vol. 5 No. 2, pp. 57-59, doi: 10.35502/jcswb.132.

Maskály, J., Ivkovic, S.K. and Neyroud, P. (2021), "Policing the COVID-19 pandemic: exploratory study of the types of organizational changes and police activities across the globe", International Crime Justice Review, Vol. 31 No. 3, pp. 1-20, doi: 10.1177/10575677211012807.

Mian, A. and Khan, S. (2020), "Coronavirus: the spread of misinformation", BMC Medicine, Vol. 18 No. 1, pp. 1-2, doi: 10.1186/s12916-020-01556-3.

Navin, K., Kuppili, P.P. and Menon, V. (2020), "Repurposing selective serotonin reuptake inhibitors for COVID-19: rationale and concerns", Indian Journal of Psychological Medicine, Vol. 42 No. 6, pp. 578-580, doi: 10.1177/0253717620963338.

Order INT/226 (2020), "Orden INT/226/2020, de 15 de marzo, por la que se establecen criterios de actuación para las Fuerzas y Cuerpos de Seguridad en relación con el Real Decreto 463/2020, de 14 de marzo, por el que se declara el estado de alarma para la gestión de la situación de crisis sanitaria ocasionada por el COVID-19”, «BOE» núm. Vol. 68, de 15 de marzo de 2020, pp. 25404-25413, available at: https://www.boe.es/buscar/doc.php?id=BOE-A-2020-3694.

Organic Law 4 (1981), "Ley Orgánica 4/1981, de 1 de junio, de los estados de alarma, excepción y sitio". «BOE» núm. 134, de 05/06/1981, available at: https://www.boe.es/buscar/act.php?id=BOE-A$1981-12774$.

Organic Law 6 (1997), "Ley Orgánica 6/1997, de 15 de diciembre, de Transferencia de Competencias Ejecutivas en Materia de Tráfico y Circulación de Vehículos a Motor a la Comunidad Autónoma de Cataluña". «BOE» núm. 300, de 16 de diciembre de 1997, pp. 36619-36620, available at: https://www.boe.es/buscar/doc.php?id=BOE-A-1997-26918.

Pappa, S., Ntella, V., Giannakas, T., Giannakoulis, V.G., Papoutsi, E. and Katsaounou, P. (2020), "Prevalence of depression, anxiety, and insomnia among healthcare workers during the COVID-19 pandemic: a systematic review and meta-analysis", Brain, Behavior, and Immunity, Vol. 88, pp. 901-907, doi: 10.1016/j.bbi.2020.05.026.

Prouska, R. and Psychogios, A. (2019), "Should I say something? A framework for understanding silence from a line manager's perspective during an economic crisis", Economic and Industrial Democracy, Vol. 40 No. 3, pp. 611-635, doi: 10.1177/0143831X17752869.

\section{Response of law enforcement agencies}


PIJPSM 45,1
Riedy, S.M., Fekedulegn, D., Vila, B., Andrew, M. and Violanti, J.M. (2021), "Shift work and overtime across a career in law enforcement: a 15-year study”, Policing, Vol. 44 No. 2, pp. 200-212, doi: 10. 1108/PIJPSM-08-2020-0134.

Royal Decree 463/2020, "Real Decreto 463/2020, de 14 de marzo, por el que se declara el estado de alarma para la gestión de la situación de crisis sanitaria ocasionada por el COVID-19”. "BOE» núm. 67, de 14/03/2020, available at: https://boe.es/buscar/act.php?id=BOE-A-2020-3692.

Stein, R.A., Ometa, O., Pachtman Shetty, S., Katz, A., Popitiu, M.I. and Brotherton, R. (2021), "Conspiracy theories in the era of COVID-19: a tale of two pandemics", International Journal of Clinical Practice, Vol. 75 No. 2, pp. 1-5, doi: 10.1111/ijcp.13778.

Stogner, J., Miller, L., Mclean, K., Stogner, J., Miller, B.L. and McLean, K. (2020), "Police stress, mental health, and resiliency during the CoViD-19 pandemic", American Journal of Criminal Justice, Vol. 45 No. 4, pp. 718-730, available at: https://link.springer.com/article/10.1007/s12103-02009548-y.

Tummers, L.L.G., Bekkers, V., Vink, E. and Musheno, M. (2015), “Coping during public service delivery: a conceptualization and systematic review of the literature on JSTOR”, Journal of Public Administration Research and Theory: J-PART, Vol. 25 No. 4, pp. 1099-1126, available at: https://www.jstor.org/stable/24484960?seq=1.

Vieta, E., Pérez, V. and Arango, C. (2020), "Psychiatry in the aftermath of COVID-19", Revista de Psiquiatria y Salud Mental, Vol. 13 No. 2, pp. 105-110, doi: 10.1016/j.rpsm.2020.04.004.

Wagner, S., White, N., Matthews, L.R., Randall, C., Regehr, C., White, M., Alden, L.E., Buys, N., Carey, M.G., Corneil, W., Fyfe, T., Krutop, E., Fraess-Phillips, A. and Fleischmann, M.H. (2019), "Depression and anxiety in policework: a systematic review", Policing, Vol. 43 No. 3, pp. 417-434, doi: 10.1108/PIJPSM-03-2019-0040. 


\section{Appendix}

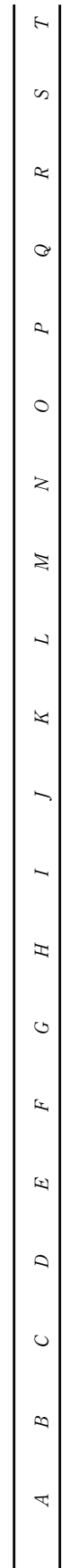

\section{$\underset{8}{8}$}

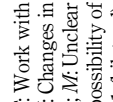

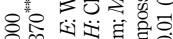
O용

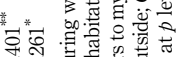

8

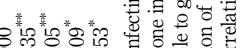
ठำ

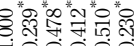
t*

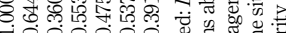
*

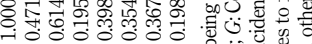
***

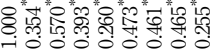

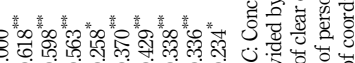
0.0 *

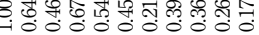
8 俈,

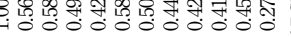

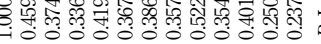

\&

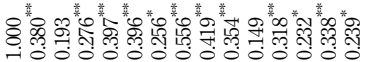

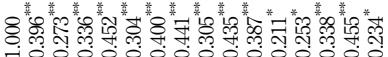

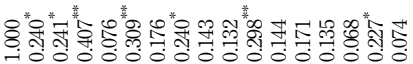

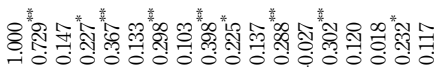

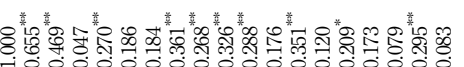
政

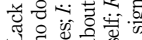

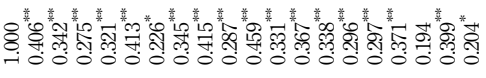

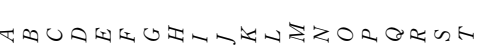

Table A1. Spearman correlations between the main difficulties experienced by officers 


\section{PIJPSM 45,1}

\begin{abstract}
About the authors
Ana Martínez-Catena is an Assistant Lecturer of Psychology and Criminology by the University of Barcelona (Spain). She is a member of the Group of Advanced Studies on Violence (GEAV) at the Universitat de Barcelona. Her research interests and teaching experience are on the fields of sex offenders' treatment and prevention, juvenile delinquency and violence against woman. Ana was also coordinator of an after-prison service to support violent delinquents to reintegrate into the community. Also participated in the specialized training of personal and social skills of the police officers of Catalunya at the Institut de Seguretat Pública de Catalunya. Ana Martínez-Catena is the corresponding author and can be contacted at: a.martinez.catena@ub.edu

Montse Subirana-Malaret is a member of the Group of Advanced Studies on Violence (GEAV) at the Universitat de Barcelona, where she carries on one of her lines of research and intervention, focused on prevention and treatment of crime. She is also experienced assessing men in batterer intervention programs. She expanded her horizon as a Postdoctoral Visiting Fellow at Dalhousie University (at the Gender and Health Promotion Studies Unit), and as a Visiting Fellow at the City University of HongKong. She also collaborates in the specialized training of personal and social skills of the public security forces at the Institut de Seguretat Pública de Catalunya.

Falgars Subirana-Malaret works at the Police of the Generalitat de Catalunya-Mossos d'Esquadra. She has a Degree in Psychology and is an expert in criminalistics science. She currently teaches in the field of criminalistics at the Police of the Generalitat de Catalunya-Mossos d'Esquadra. She also teaches the course of Multiple Victims and Catastrophes Accidents and has been a speaker in the Master's Degree in Outpatient Emergencies, both at the Fundació Unversitària del Bages and at the Universitat de Vic-Universitat Central de Catalunya. In addition, she collaborates in several specialisation courses.
\end{abstract}

For instructions on how to order reprints of this article, please visit our website:

www.emeraldgrouppublishing.com/licensing/reprints.htm

Or contact us for further details: permissions@emeraldinsight.com 